\title{
ANALISIS PENGARUH CAR, KUALITAS ASET PRODUKTIF, KUALITAS MANAJEMEN, BOPO DAN LIKUIDITAS TERHADAP PROFITABILITAS \\ (Studi Kasus Perusahaan Perbankan Yang Terdaftar Di BEI Tahun 2012 - 2016)
}

\author{
Irsyad Hanafiah, Desfriana Sari \\ Program Studi Manajemen, STIE “KBP” Padang \\ irsyadhanafiah@gmail.com
}

\begin{abstract}
The soundness of a bank can be seen with several indicators. Some of the indicators are the main indicators on which the valuation is based. Financial statement analysis can help users of financial statements in assessing the financial condition of the bank. In assessing the bank's financial condition, some ratios are Capital Adequacy Ratio (CAR), Non Performing Loan (NPL), Net Interest Margin (NIM), Operating Income Operating Cost (BOPO) and Loan to Deposit Ratio (LDR) as independent variable. The purpose of this study to see and test how the influence of these ratios on bank profitability as a dependent variable. The research was conducted at a banking company listed on the Indonesia Stock Exchange. The samples of this research are 20 banks listed on Indonesia Stock Exchange in 2012 - 2016. Test data in this research using E-Views 6 statistical application, the result of this research shows that CAR has negative and significant effect on profitability, NPL has negative and insignificant on profitability, NIM positively and significantly affect profitability, BOPO has a negative and significant effect on profitability and LDR have negative and insignificant effect on profitability.
\end{abstract}

Keywords: CAR, NPL, NIM, BOPO, LDR, Profitability

\section{PENDAHULUAN}

Perkembangan perekonomian yang semakin kompleks tentunya membutuhkankan ketersediaan dan peran lembaga keuangan. Kebijakan moneter dan perbankan merupakan bagian dari kebijakan ekonomi yang diarahkan untuk mencapai sasaran pembangunan. Hampir semua sektor usaha maupun individu membutuhkan bank sebagai mitra dalam melakukan transaksi keuangan baik saat ini maupun yang akan datang dalam mendukung kelancaran usaha. Peran bank bagi masyarakat individu maupun masyarakat bisnis sangat penting bahkan bagi suatu negara, karena bank sebagai suatu lembaga yang sangat berperan dan berpengaruh dalam perkenomian suatu negara (Ismail, 2011:2). Oleh karena itu, bank juga disebut sebagai lembaga perantara keuangan (financial intermediary).

Sebagai lembaga perantara keuangan atau financial intermediary, kegitatan utama suatu bank yaitu menghimpun dana dari masyarakat yang kelebihan dana (surplus) melalui simpanan dan kemudian meyalurkan dana tersebut kepada masyarakat yang kekurangan dana (deficit) dalam bentuk kredit atau pinjaman (Kasmir, 2008) dalam (Septiadi 2014). Dalam kegiatan utama bank, bank selalu berhati-hati dalam mengelola sumber dana masyarakat, karena kesalahan dalam mengelola sumber dana masyarakat ataupun kesalahan dalam 
mengalokasikan dana akan berakibat pada penurunan kepercayaan masyarakat kepada bank. Bank yang merupakan perusahaan yang bergerak dalam usaha jasa, dimana kepercayaan masyarakat akan menempati porsi yang sangat besar dalam menjaga kelangsungan hidap bank, karena kelangsungan hidup bank sangat ditentukan oleh kepercayaan masyarakat (Ismail, 2011: 11).

Penilaian kondisi bank dapat dilakukan dengan menganalisis laporan keuangan bank yang bersangkutan sehingga didapat informasi mengenai kondisi bank yang digunakan baik dari pihak bank itu sendiri maupun pihak luar seperti kreditur, investor dan nasabah. Penilaian kesehatan bank dikenal dengan motode CAMELS, metode ini digunakan untuk menilai kesehatan bank dengan cara menghitung masing-masing rasio pada komponen-komponen yang meliputi aspek kecukupan modal bank, (Capital), kualitas aset produktif (Assets), kualitas manajemen (Management), Rentabilitas (Earning), Likuiditas (Liquidity), dan sensitivitas terhadap risiko pasar (Sensitivity to Market Risk) (Kasmir, 2010) dalam (Arinta 2015).

Berdasarkan Surat Edaran Bank Indonesia No. 6/13/DPNP tanggal 31 Mei 2004, dimana Bank Indonesia yang bertugas sebagai pengawas dan pengatur perbankan terhitung sejak tanggal 31 Desember 2013 dialihkan kepada Otoritas Jasa Keuangan menentukan standar yang paling baik untuk Return On Asset (ROA) yaitu $1,25 \%$ (predikat sehat). ROA sangat penting digunakan untuk mengukur kinerja profitabilitas bank dalam memperoleh keuntungan (laba) secara keseluruhan. Berdasarkan penelitian yang dilakukan (Sari 2010), (Hutagalung, Djumahir, and Ratnawati 2011), (Wibisono 2013), (Harun 2016) dan (Prasanjaya and Ramantha 2013) ROA yang digunakan untuk mengukur kinerja profitabilitas dalam menghasilkan laba secara efektif dan efisien dipengaruhi oleh Capital Adequacy Ratio (CAR), kualitas aset produktif (NPL), kualitas manajemen (NIM), Biaya Operasional Pendapatan Operasional (BOPO) dan likuiditas (LDR).

Besarnya rata-rata ROA, CAR, NPL, NIM, BOPO dan LDR perbankan yang terdaftar di Bursa Efek Indonesia sesuai dengan kriteria sampel dalam penelitian sebanyak 20 perbankan tahun 2012 - 2016. Rata-rata CAR perbankan mengalami fluktuasi selama periode pengamatan dan telah sesuai dengan standar yang ditetapkan Bank for International Settlement (BIS) yaitu di atas 8\%, yang berarti perbankan di Indonesia memiliki CAR yang dikategorikan berpredikat sehat. Pada tahun 2013 CAR mengalami penurunan menjadi 17,56\%, sedangkan ROA mengalami juga mengalami penurunan menjadi $2,64 \%$ pada tahun yang sama. Pada tahun 2015 CAR mengalami peningkatan menjadi 18,36\%, sedangkan ROA mengalami penurunan menjadi $1,93 \%$ dari tahun sebelumnya, hal tersebut tidak sesuai dengan teori yang menyatakan CAR berhubungan positif terhadap ROA, jika CAR turun seharusnya ROA juga mengalami penurunan.

Rata-rata NPL perbankan mengalami fluktuasi meningkat dan selama periode pengamatan rata-rata NPL sudah berada di bawah $6 \%$ sesuai dengan ketentuan Bank Indonesia, hal ini menunjukkan bahwa kemampuan bank dalam mengelola kredit bermasalah dengan tingkat kolektabilitas kurang lancar, diragukan dan macet sudah tergolong baik sehingga NPL perbankan dapat dikatakan berpredikat sehat. Rata-rata NPL pada tahun 2016 mengalami peningkatan menjadi $1,71 \%$, ternyata rata-rata ROA juga ikut meningkat menjadi 
2,04\%. Berbeda dengan tahun 2015 dimana NPL mengalami peningkatan menjadi 1,51 dari tahun sebelumnya sedangkan ROA mengalami penurunan menjadi $1,74 \%$ dari tahun sebelumnya, hal tersebut tidak sesuai dengan teori yang menyatakan NPL meningkat seharusnya ROA turun.

Rata-rata NIM perbankan selama tahun 2012-2016 mengalami fluktuasi dan telah sesuai dengan standar ketetapan Bank Indonesia yaitu di atas 1,5\%, yang berarti bank mampu menghasilkan pendapatan bunga bersih dari rata-rata aset produktif dengan kategori bank berpredikat sehat. Pada tahun 2014 hubungan antara NIM dengan ROA sesuai dengan teori, dimana rata-rata NIM mengalami penurunan menjadi $5,45 \%$ yang diikuti dengan penurunan ROA menjadi sebesar 1,89\%. Pada tahun 2015 NIM mengalami peningkatan menjadi sebesar $1,93 \%$ dari tahun sebelumnya, hal tersebut bertentangan dengan teori yang menyatakan NIM memiliki hubungan positif terhadap ROA, jika NIM turun seharusnya ROA juga ikut turun.

Rata-rata BOPO perbankan mengalami kecendrungan berfluktuasi naik selama periode pengamatan dan sesuai dengan ketentuan Bank Indonesia maksimum 90\%. Pada tahun 2013 BOPO mengalami peningkatan menjadi $75,94 \%$ tetapi ROA pada tahun yang sama mengalami penurunan menjadi $2,64 \%$ dari tahun sebelumnya. Pada tahun 2016 BOPO mengalami penurunan menjadi $81,40 \%$ dari tahun sebelumnya dan ROA mengalami peningkatan menjadi $2,04 \%$ dari tahun sebelumnya, hal ini menunjukan sesuai dengan teori dimana jika BOPO menurun maka ROA meningkat.

Rata-rata LDR perbankan mengalami fluktuasi selama periode pengamatan, LDR perbankan telah sesuai dengan standar batas aman yaitu sekitar 85\%-110\% yang artinya likuiditas bank dapat dikategorikan berpredikat sehat. Pada tahun 2013 rata-rata LDR meningkat menjadi 87,784\%, tetapi pada tahun yang sama ROA menurun menjadi 2,64\%. Pada tahun 2015 LDR menurun menjadi $85,48 \%$ dan ROA juga ikut menurun menjadi $1,93 \%$ dari tahun sebelumnya, hal tersebut tidak sesuai dengan teori yang menyatakan jika LDR turun seharusnya ROA juga ikut turun.

\section{TINJAUAN PUSTAKAN}

\section{Bank}

Menurut Undang-Undang Perbankan No. 10 Tahun 1998 yang dimaksud dengan bank adalah badan usaha yang menghimpun dana dari masyarakat dalam bentuk simpanan dan menyalurkannya ke masyarakat dalam bentuk kredit ataupun bentuk-bentuk lainnya dalam rangka meningkatkan taraf hidup rakyat banyak. Sedangkan menurut Ade dan Edia (2006) dalam (Septiadi 2014) "Bank merupakan salah satu lembaga keuangan yang berfungsi sebagai financial intermediary atau lembaga perantara antara pihak yang kelebihan dana (surplus) dan pihak yang kekurangan dana (deficit). Sehingga, bank akan membantu pertumbuhan perekonomian Indonesia melalui pengeloaan dana yang tersimpan kemudian dana tersebut dimanfaatkan bagi peningkatan kesejahteraan masyaraka." 


\section{Tingkat Kesehatan Bank}

Penilaian kesehatan bank amat penting disebabkan karena bank mengelola dana masyarakat yang dipercayakan kepada bank. Penilaian ini bertujuan untuk menentukan apakah bank tersebut dalam kondisi sehat, cukup sehat, kurang sehat, ataupun tidak sehat. Bagi bank yang sehat agar tetap mempertahankan kesehatannya, sedangkan bank yang sakit untuk segera mengobati penyakitnya. Bank Indonesia sebagai pengawas dan pembina bank-bank dapat memberikan arahan atau petunjuk bagaimana bank tersebut harus dijalankan atau bahkan kalau perlu dihentikan kegiatan operasinya (Kasmir, 2012: 46).

\section{Profitabilitas}

Profitabilitas adalah kemampuan perusahaan untuk mendapatkan laba melalui semua kemampuan dan sumber daya yang ada seperti kegiatan penjualan, kas, modal, jumlah karyawan, jumlah cabang dan sebagainya. Rasio profitabilitas yang menggambarkan kemampuan perusahaan menghasilkan laba dapat disebut Operating Ratio (Sofyan, 2007) dalam (Alhaq, Taufik, and Desmiyawati 2011)

Dengan memperoleh laba atau keuntungan seperti yang telah ditargetkan, perusahaan dapat berbuat banyak bagi kesejahteraan pemilik, karyawan, serta mutu produk dan melakukan investasi baru. Oleh karena itu, manajemen perusahaan dalam praktiknya dituntut harus mampu untuk memenuhi target yang telah ditetapkan. Artinya, keuntungan yang dicapai haruslah sesuai dengan yang diharapkan dan bukan hanya asal untung saja. Untuk mengukur tingkat keuntungan suatu perusahaan tersebut, maka dapat digunakan rasio profitabilitas atau yang sering dikenal dengan rasio rentabilitas (Kasmir, 2013:196).

\section{Faktor-faktor yang Mempengaruhi Profitabilitas Perbankan}

1. Capital Adequacy Ratio (CAR)

Capital Adequacy Ratio merupakan indikator penilaian dari aspek permodalan bank dalam menutup penurunan aktiva sebagai akibat kerugian yang diderita bank. Besar kecilnya CAR ditentukan oleh kemampuan bank dalam menghasilkan laba dan pengalokasian dana pada aktiva sesuai tingkat risikonya. Menurut (Iswi, 2010: 58) CAR mempunyai hubungan positif terhadap perubahan laba yang diukur dengan menggunakan ROA, kondisi ini menunjukkan penggunaan utang akan meningkatkan tambahan laba yang diperoleh bank karena pengembalian dari dana melebihi bunga yang harus dibayarkan.

\section{Kualitas Aset Produktif}

Rasio NPL (Non Performing Loan) merupakan rasio yang digunakan untuk menilai kualitas aset produktif suatu bank yang berkaitan dengan risiko kredit (Infobanknews 2013). Menurut (Iswi, 2010: 52) Rasio NPL menunjukkan bahwa kemampuan manajemen bank dalam mengelola kredit bermasalah dengan kualitas kurang lancar, diragukan dan macet. Semakin tinggi rasio ini maka akan semakin buruk kualitas kredit bank yang menyebabkan jumlah kredit bermasalah semakin besar, sehingga mengindikasikan laba yang diperoleh bank atau ROA semakin rendah. 


\section{Kualitas Manajemen}

Kualitas manajemen pada bank dapat dinilai secara lebih objektif dengan melihat catatan kinerja keuangan selama beberapa periode. Kinerja keuangan tersebut dinilai berdasarkan kemampuan bank dalam menjaga tingkat efisiensi bank (Sjamsul dan Dian, 2007) dalam (Septiadi 2014). Menurut (Sindonews 2013) Indikator efisiensi bank dapat diukur dengan rasio Net Interest Margin (NIM) yang berasal dari suku bunga yang diterima dikurangi suku bunga yang dibayar dibagi rata-rata aset investasi. Semakin tinggi NIM maka semakin tinggi pula laba yang diperoleh bank yang mengindikasikan ROA semakin tinggi.

\section{BOPO}

Biaya Operasional Pendapatan Operasional (BOPO) digunakan untuk mengukur tingkat efisiensi dan kemampuan bank dalam melakukan kegiatan operasinya. Mengingat kegiatan utama bank pada prinsipnya adalah bertindak sebagai perantara, maka biaya dan pendapatan operasional bank didominasi oleh biaya bunga dan hasil bunga. Setiap penigkatan biaya operasional akan berakibat pada berkurangnya laba sebelum pajak yang pada akhirnya akan menurunkan laba atau profitabilitas (ROA) bank yang bersangkutan (Dendawijaya, 2003) dalam (Alifah 2014). Berdasarkan Surat Edaran Bank Indonesia No.6/23/DPNP tanggal 31 Mei 2004, jika BOPO sering dibuat sebagai rasio efisiensi ini digunakan untuk mengukur kemampuan manajemen bank dalam mengendalikan manajemen bank dalam mengendalikan biaya operasional terhadap pendapatan operasional dengan batas maksimum $90 \%$.

\section{Likuiditas}

Salah satu cara mengukur tingkat likuiditas bank yaitu menggunakan rasio LDR (Loan to Deposit Ratio). Rasio LDR merupakan rasio kredit yang diberikan terhadap dana pihak ketiga yang diterima oleh bank yang bersangkutan. Besarnya LDR akan berpengaruh terhadap laba melalui penciptaan kredit. LDR yang tinggi mengindikasikan besarnya penanaman dana dari pihak ketiga dalam bentuk kredit. Sehingga, dengan besarnya penanaman dana tersebut maka ROA atau laba yang diperoleh bank akan meningkat (Iswi, 2010:57).

\section{Hipotesis}

Berdasarkan latar belakang penelitian dan teori - teori yang mendukung seperti yang telah dikemukakan sebelumnya, maka dikemukakan hipotesis penelitian sebagai berikut :

H1 = Diduga CAR pengaruh positif signifikan terhadap Profitabilitas perbankan yang terdaftar di BEI.

H2 = Diduga NPL pengaruh positif signifikan terhadap Profitabilitas perbankan yang terdaftar di BEI

H3 = Diduga NIM pengaruh positif signifikan terhadap Profitabilitas perbankan yang terdaftar di BEI

H4 = Diduga BOPO pengaruh positif signifikan terhadap Profitabilitas perbankan yang terdaftar di BEI

H5 = Diduga LDR pengaruh positif signifikan terhadap Profitabilitas perbankan yang terdaftar di BEI

\section{METODE PENELITIAN}


Penelitian ini dilakukan dengan mengambil perusahaan perbankan yang terdaftar di Bursa Efek Indonesia tahun 2012 - 2016, dengan populasi seluruh perbankan yang terdaftar di Bursa Efek Indoensia yang mempublikasikan laporan keuangan secara berturut - turut selama tahun 2012 hingga 2016. Adapun teknim pengambilan sampel penelitian ini menggunakan teknik purposive sampling dengan beberapa kriteria, sehingga sampel penelitian ini adalah 20 perusahaan perbankan. Pada penelitian ini, pengolahan data menggunakan aplikasi statistik EViews 6.

\section{Teknik Analisis Data}

Teknik pengumpulan data yang digunakan dalam penelitian ini adalah teknik dokumentasi yaitu suatu teknik pengumpulan data dengan mempelajari dan menggunakan laporan keuangan pihak emiten yang menjadi sampel dalam penelitian ini. Dengan teknik ini penulis mengumpulkan data laporan keuangan perusahaan dari tahun 2012-2016 yang terkait dengan ROA, CAR, NPL, NIM, BOPO dan LDR. Data ini diperoleh melalui situs resmi Bursa Efek Indonesia (BEI) www.idx.co.id.

\section{Analisis Statistik Deskriptif}

Digunakan untuk memberikan gambaran mengenai faktor - faktor yang mempengaruhi variable, baik secara numerik misalnya menghitung rata - rata, standar deviasi atau secara grafis dalam bentuk tabel atau grafik. Untuk mendapatkan gambaran umum tentang data yang diperoleh sebagai acuan untuk melihat karakteristik data yang diperoleh.

\section{Uji Asumsi Klasik}

Uji asumsi klasik digunakan untuk mendapatkan penduga koefisien regresi yang mempunyai erorr terkecil atau model regresi yang dihasilkan adalah mempunyai sifat BLUE (Best Linear Unbiased Estimate) atau mempunyai sifat yang linear, tidak bias dan varian minimu.

\section{Regresi Panel}

Panel data merupakan gabungan antara jenis data time series dan cross section sehingga panel data merupakan data yang memiliki dimensi waktu dan ruang. Nama lain dari panel data diantaranya pooled data, combination of time series and cross section data, micropanel data, longitudinal data, event history analysis ataupun cohort analysis."

Untuk mengestimasi parameter model dengan data panel, terdapat beberapa teknik yang ditawarkan yaitu Ordinary Least Square, Model Efek Tetap (Fixed Effect Model), dan Model Efek Random (Random Effect Model).

\section{Ordinary Least Square}

Ordinary Least Square merupakan pendekatan yang paling sederhana dalam pengolahan data panel yaitu menggabungkan data cross section dengan data time series (pool data). Dengan menggabungkan jenis data cross section dan time series maka gabungan data tersebut diperlakukan sebagai satu 
kesatuan pengamatan yang tidak dapat dilihat perbedaan baik antar individu maupun antar waktu. Persamaan dengan model ini sebagai berikut :

$$
Y_{i t}=\beta_{0 i}+\beta_{j} X_{i j t}+e_{i t}
$$

Dimana:

$Y_{i t}=$ nilai variabel terikat untuk setiap unit cross section .

$\beta_{0 i}=$ intercept yang konstan antar waktu dan cross section.

$\beta_{j}=$ slope untuk variabel ke-j yang konstan antar waktu dan cross section.

$X_{i j t}=$ nilai variabel bebas ke-j untuk setiap cross section .

$e_{i t}=$ komponen error untuk setiap unit cross section ke- $i$ pada periode waktu $t$

\section{Model Efek Tetap (Fixed Effect Model)}

Fixed Effect Model merupakan suatu model yang dapat menunjukkan perbedaan konstan antarobjek, meskipun dengan koefisien regresor yang sama. Maksudnya adalah bahwa satu objek, memiliki konstan yang tetap besarnya untuk berbagai periode waktu. Untuk membedakan satu objek dengan objek lainnya, digunakan variabel semu (dummy). Oleh karena itu, model ini sering disebut Least Square Dummy Variables (LSDV). Kelebihan dari model ini adalah dapat menghasilkan dugaan parameter $\beta$ yang tidak bias dan efisien. Tetapi metode ini juga memiliki kelemahan yaitu jika jumlah unit observasinya besar maka akan terlihat rumit. Persamaan dengan metode ini adalah:

$$
Y i t=\beta_{0 i}+\beta_{1} X_{1 i t}+\beta_{2} X_{2 i t}+\beta_{3} d_{3 i t}+\beta_{4} d_{4 i t}+\beta_{5} d_{5 i t}+e_{i t}
$$

\section{Model Efek Random (Random Effect Model)}

Efek random digunakan untuk mengatasi kelemahan model efek tetap yang menggunakan variabel semu, sehingga model mengalami ketidakpastian. Tanpa menggunakan variabel semu, model efek random menggunakan residual, yang diduga memiliki hubungan antar waktu dan antar subjek. Persamaan yang digunakan dalam model ini sebagai berikut:

$$
Y i t=\beta_{0 i}+\beta_{1} X_{1 i t}+\beta_{2} X_{2 i t}+e_{i t}
$$

Tidak seperti pada model efek tetap ( $\beta_{0}$ dianggap tetap), pada model efek random $\beta_{0}$ diasumsikan bersifat acak, sehingga dapat dituliskan dalam persamaan:

$$
\beta=\bar{\beta}_{0}+u_{i}, i=1, \ldots, n
$$

\section{Pemilihan Model}

a. Uji chow digunakan untuk memilih model yang tepat dalam data panel antara Ordinary Least Square dan fixed effect model. Pengujian ini menggunakan hipotesis:

$$
\begin{aligned}
& \mathrm{H}_{0}: \beta_{1}=0=\text { OLS Model } \\
& \mathrm{H}_{1}: \beta_{2} \neq 0=\text { Fixed Effect Model }
\end{aligned}
$$

b. Pengujian Hausman dilakukan untuk memilih model terbaik antara fixed effect dan random effect. Menurut Nachrowi dan Hardius (2006: 318) dalam Septiadi (2014) "Mengingat random effect yang diduga 
dengan menggunakan model data panel, maka uji hausman dapat digunakan untuk melihat kelayakan penggunaan model data panel tersebut." Memilih antara penggunaan random effect dan fixed effect, maka digunakan pertimbangan statistik Chi-Square. Pegujian ini menggunakan hipotesis:

$\mathrm{H}_{0}: \beta_{1}<0,05=$ Fixed Effect Model
$\mathrm{H}_{1}: \beta_{2}>0,05=$ Random Effect Model

\section{Uji Normalitas Data}

Uji normalitas adalah bertujuan untuk menguji apakah dalam model regresi, variable pengganggu atau residual mempunyai distribusi normal atau tidak (Ghozali, 2006:110) dalam (Sansoethan and Suryono 2016) . Uji normalitas digunakan untuk menguji apakah sebuah model regresi, variabel dependen, variabel independen, dan keduanya mempunyai distribusi normal atau tidak. Model regresi yang baik adalah data distribusi normal dan merata. Uji normalitas bertujuan untuk menguji apakah model regresi, variabel pengganggu atau residual mempunyai distribusi normal atau tidak. Data distribusi normal dapat dilihat jika nilai probability Jarque-Bera> tingkat alpha 5\% maka data terdistribusi secara normal, sebaliknya jika nilai probability Jarque-Bera< tingkat alpha 5\% maka data tidak terdistribusi secara normal.

\section{Analisi Model Regresi Panel}

Secara sistematis dalam penelitian ini enguji pengaruh Capital Adequacy Ratio (CAR). kualitas aset produktif, kualitas manajemen, Biaya Operasional Pendapatan Operasional, dan likuiditas terhadap profitabilitas dapat dirumuskan sebagai berikut :

Dimana :

$$
\mathrm{Y}=\mathrm{a}+\mathrm{b}_{1} \mathrm{x}_{1 \mathrm{i}, \mathrm{t}}+\mathrm{b}_{2} \mathrm{x}_{2 \mathrm{i}, \mathrm{t}}+\mathrm{b}_{3} \mathrm{x}_{3 \mathrm{i}, \mathrm{t}}+\mathrm{b}_{4} \mathrm{x}_{4 \mathrm{i}, \mathrm{t}}+\mathrm{b}_{5} \mathrm{x}_{5 \mathrm{i}, \mathrm{t}}+\mathrm{e}
$$

$$
\begin{aligned}
& \mathrm{Y}=\text { Profitabilitas } \\
& \mathrm{a}=\text { Konstanta } \\
& \mathrm{b}_{1 \ldots ., \mathrm{b}} \quad=\text { Koefisien Regresi } \\
& \mathrm{x}_{1 \mathrm{i}, \mathrm{t}} \quad=\text { CAR } \\
& \mathrm{x}_{2 \mathrm{i}, \mathrm{t}} \quad=\mathrm{NPL} \\
& \mathrm{x}_{3 \mathrm{i}, \mathrm{t}} \quad=\mathrm{NIM} \\
& \mathrm{x}_{4 \mathrm{i}, \mathrm{t}} \quad=\mathrm{BOPO} \\
& \mathrm{x}_{5 \mathrm{i}, \mathrm{t}} \quad=\text { LDR } \\
& \mathrm{e}=\text { Standar Error }
\end{aligned}
$$

\section{Uji Hipotesis}

Setelah dinyatakan bebas dari penyimpangan asumsi klasik selanjutnya adalah pengujian secara statistik untuk mengetahui apakah semua variabel independenya memang secara bersama - sama atau parsial mempunyai pengaruh nyata terhadap variabel dependennya. Uji satistik adalah menguji apakah hasil yang dicapai sudah sesuai dengan metode - metode statistik yang ada, meliputi :

1. Uji F (Simultan)

Uji $F$ digunakan untuk menguji pengaruh variabel independen secara bersama - sama terhadap variabel dependen dari suatu persamaan regresi yang 
didasarkan pada nilai probabilitas $\mathrm{a}=0,05$ dengan kriteria pengujian sebagai berikut :

Jika probabilitas > 0,05 $\mathrm{H}_{\mathrm{a}}$ ditolak, $\mathrm{H}_{\mathrm{o}}$ diterima

Jika probabilitas $<0,05 \mathrm{H}_{\mathrm{a}}$ diterima, $\mathrm{H}_{\mathrm{o}}$ ditolak

2. Uji t (Persial)

Uji $\mathrm{t}$ digunakan untuk menguji pengaruh variabel independen secara persial terhadap variabel dependen yaitu pengaruh dari variabel independen terhadap variabel dependen yaitu yang didasarkan pada nilai probabilitas a = 0,05 dengan kriteria pengujian sebagai berikut :

Jika probabilitas $>0,05 \mathrm{H}_{\mathrm{a}}$ ditolak, $\mathrm{H}_{\mathrm{o}}$ diterima

Jika probabilitas $<0,05 \mathrm{H}_{\mathrm{a}}$ diterima, $\mathrm{H}_{\mathrm{o}}$ ditolak

3. Analisis Koefisien Determinasi Multiple $\left(\mathrm{R}^{2}\right)$

Suharyadi dan Purwanto (2004:514) dalam (Ichwan and Widyawati 2015) menyatakan bahwa koefisien determinasi merupakan ukuran untuk mengetahui kesesuaian atau ketepatan hubungan antara variabel independen dengan variabel dependen dalam persamaan suatu regresi. Koefisien determinasi digunakan untuk mengetahui hubungan antara variabel independen terhadap variabel dependen. Koefisien determinasi berkisar dari 0 sampai dengan 1 ( $0 \leq \mathrm{R} 2$ $\leq 1$ ). Hal ini berarti bila $\mathrm{R} 2=0$ menunjukkan tidak adanya pengaruh antara variabel dependen, apabila R2 semakin besar terhadap variabel dependen dan bila R2 semakin kecil mendekati 0 maka dapat dikatakan semakin kecilnya pengaruh variabel independen terhadap variabel dependen.

\section{HASIL DAN PEMBAHASAN}

Deskripsi variabel penelitian in bertujuan untuk melihat karakteristik variabel variabel yang diteliti. Penelitian ini memiliki lima variabel bebas dan yaitu Capital Adequacy Ratio (CAR), Non Performing Loan (NPL), Net Interest Margin (NIM), Biaya Operasional Pendapatan Operasional (BOPO) dan Likuiditas (LDR) yang mempengaruhi variabel terikat yaitu profitabilitas (ROA) pada perbankan yang terdaftar di Bursa Efek Indonesia pada tahun 2012 - 2016.

Profitabilitas perbankan yang diukur dengan menggunakan rasio ROA selama tahun 2012-2016 mendapatkan hasil nilai tertinggi sebesar 5,150\% sedangkan nilai terendah adalah $0,240 \%$ dengan nilai rata - rata 2,269\%. Nilai terendah adalah $0,240 \%$, disini dapat dijelaskan bahwa pada periode pengamatan masih ada perbankan yang berada pada predikat tidak sehat menurut ketentuan Bank Indonesia yaitu ROA pada kisaran $0,00 \%-0,77 \%$. Predikat kurang sehat ini sebabkan oleh kemampuan bank dalam menghasilkan laba sebelum pajak yang masih rendah jika dibandingkan dengan rata - rata total aset yang dimiliki oleh bank. Tetapi jika dilihat dari rata - rata ROA sebesar 2,269\% menunjukan bahwa ROA selama periode pengamatan telah sesuai dengan ketentuan Bank Indonesia yang itu diatas $1,25 \%$ dengan standar deviasi sebesar 1,092\%.

CAR memiliki nilai tertinggi $42,520 \%$ dan nilai terendah $10,440 \%$, sedangkan nilai rata - rata selama periode pengamatan adalah $18,172 \%$ dengan 
standar deviasi $4,340 \%$. CAR pada setiap tahunnya dapat dikategorikan berpredikat sehat karena sudah diatas $8,00 \%$ berdasarkan standar ketentuan Bank Indoensia yang dibuktikan dari nilai tertinggi CAR sebesar $42,52 \%$ dan nilai terendahnya $1,044 \%$. Kondisi ini diperkuat dengan nilai rata -rata CAR sebesar $18,172 \%$ dengan standar deviasi CAR perbankan sebesar 4,340\%.

Selama 5 tahun pengamatan nilai NPL perbankan tertinggi adalah 3,680\% dan terendah adalah $0,000 \%$. Sedangkan untuk rata - rata selama 5 tahun adalah $1,399 \%$. Tinggi dan rendahnya nilai NPL perbankan yang diperoleh menunjukan kondisi yang baik setiap tahunnya, karena berada dibawah $6 \%$ predikat sehat berdasarkan ketentuan Bank Indonesia. Kondisi ini juga diperkuat dengan nilai rata - rata yang didapat dan diukur dispersi atau penyebaran data dari nilai rata ratanya sebesar $0,930 \%$ berdasarkan standar deviasi NPL perbankan.

NIM atau kualitas manajemen yang dapat dilihat pada tabel 4.1 menunjukan bahwa nilai NIM perbankan yang tertinggi sebear $13,100 \%$ dan terendah $1,890 \%$ sedangkan rata - rata selama periode pengamatan 5 tahun yaitu sebesar 5,953\% dengan standar deviasi sebesar 2,012\%. Dengan di dapatnya nilai terendah $1,890 \%$ menunjukan bahwa NIM perbankan selama tahun pengamatan dalam kondisi yang sehat menurut ketentuan Bank Indonesia yaitu dibawah 1,5 $\%$. Jika dibandingkan dengan rata - rata NIM sebesar 5,953\%, menunjukan bahwa besarnya NIM telah sesuai dengan ketentuan Bank Indonesia yaitu NIM yang baik harus diatas $1,5 \%$, disamping itu ukuran dispersi atau penyebaran data dari nilai rata - rata terlibat dari standar deviasi NIM perbankan sebesar 2,012\%.

BOPO atau biaya operasional pendapatan operasional yang dapat dilihat pada tabel 4.1 menunjukan bahwa nilai BOPO perbankan yang tertinggi sebesar $97,380 \%$ dan terendah $33,280 \%$ sedangkan rata - rata selama periode pengamatan 5 tahun yaitu sebesar 79,463\% dengan standar deviasi sebesar 10,962\%. Dengan di dapatnya nilai rata - rata NIM sebesar 79,463\%, menunjukan bahwa BOPO menunjukan predikat sehat dan telah sesuai dengan ketentuan Bank Indonesia yaitu BOPO yang baik harus dibawah 90\%, disamping itu ukuran dispersi atau penyebaran data dari nilai rata - rata sebesar $10,962 \%$ terlihat dari standar deviasi BOPO perbankan

LDR tertinggi adalah sebesar $140,720 \%$, nilai terendahnya adalah $52,390 \%$ sedangkan untuk rata - rata nya selama tahun pengamatan adalah sebesar $85,525 \%$ dengan standar deviasi sebesar $13,647 \%$. Nilai rata - rata LDR yang di dapat sebesar $85,525 \%$ masuk dalam predikat sehat berdasakan ketentuan Bank Indonesia karena dibawah 94,75\% dan dapat dijelaskan kemampuan bank yang lebih baik dalam mengoperasikan dananya, karena dana yang disalurkan untuk pihak ketiga kecil. 


\section{Regresi Panel}

\section{a. Chow-Test}

Penggunaan common effect atau fixed effect dapat dilihat pada tabel 4.2.

\section{Tabel 1 Hasil Chow - Test}

Redundant Fixed Effects Tests

Equation: Untitled

Test cross-section fixed effects

\begin{tabular}{|c|c|c|c|}
\hline Effects Test & Statistic & d.f. & Prob. \\
\hline Cross-section F & 5.970923 & $(19,75)$ & 0.0000 \\
\hline Cross-section Chi-square & 92.133156 & 19 & 0.0000 \\
\hline
\end{tabular}

Berdasarkan tabel diatas dengan menggunakan $\mathrm{E}$ - Views 6, dapat dilihat bahwa nilai probability cross-section $\mathrm{f}$ dan cross-section Chi-square sama sama sebesar 0,0000. Nilai probability lebih kecil dari nilai signifikan $\alpha 0,05$ (5\%), sehingga dapat disimpulkan bahwa $\mathrm{H}_{0}$ pada model penelitian ini ditolak dan $\mathrm{H}_{\mathrm{a}}$ diterima dan estimasi yang tepat digunakan dalam model penelitian ini adalah fixed effect.

\section{b. Hausman Test}

Penggunaan common effect atau fixed effect dapat dilihat pada hasil hausman test yang diolah menggunakan E-Views 6 dalam tabel 2 .

\section{Tabel 2 Hasil HausmanTest}

\begin{tabular}{|c|c|c|c|}
\hline \multicolumn{4}{|c|}{$\begin{array}{l}\text { Correlated Random Effects - Hausman Test } \\
\text { Equation: Untitled } \\
\text { Test cross-section random effects }\end{array}$} \\
\hline Test Summary & $\begin{array}{l}\text { Chi-Sq. } \\
\text { Statistic }\end{array}$ & Chi-Sq. d.f. & Prob. \\
\hline Cross-section random & 4.234926 & 5 & 0.5161 \\
\hline
\end{tabular}

Dari tabel hasil hausman test dapat dilihat bahwa nilai probability crosssection random sebesar 0,5161 yang lebih besar dari level signifikan $\alpha 5 \%(0,05)$, maka dapat disimpulkan bahwa $\mathrm{H}_{0}$ untuk penelitian ini diterima dan $\mathrm{H}_{\mathrm{a}}$ ditolak sehingga estimasi yang lebih baik digunakan dalam model penelitian ini adalah random

effect

\section{Uji Normalitas}

Setelah dilakukannya pengelohan data, maka didapatkan hasil uji normalitas yang dilakukan mendapatkan nilai probability sebesar $0,181234>0,05$ 
atau sebesar $18 \%>5 \%$, dapat disimpulkan bahwa data yang di uji diakatakan terdistribusi normal, hasil uji normalitas pada model penelitian sebegai berikut :

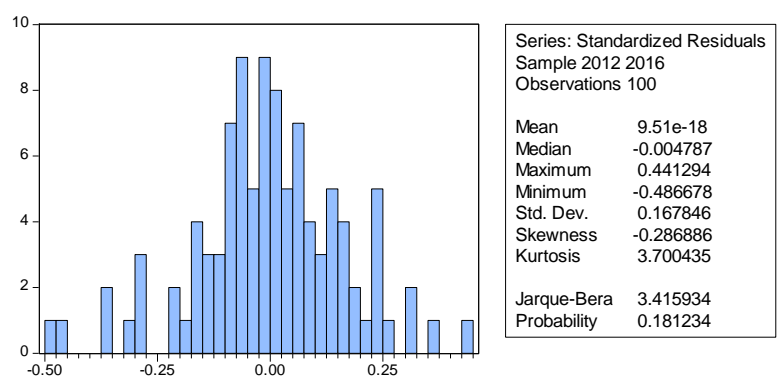

Sumber : Hasil Olahan Program E-Views 6

Gambar 1 Uji Normalitas

\section{Model Regresi Panel}

Persamaan regresi panel untuk masing - masing perusahaan sebagai berikut :

\section{ROAi,t $=8.3346-0.0213 C A R i, t-0.0221 N P L i, t+0.2354 N I M i, t-$ 0.0832BOPOi,t - 0.0051LDRi,t}

Hasil perhitungan intercept random effect model dapat disimpulkan bahwa adanya perbebdaan nilai atau konstanta dari setiap perusahaan perbankan yang menjadi sampel dalam penelitian ini. Pengaruh CAR terhadap profitabilitas secara keseluruhan yang diukur dengan ROA perbankan selama tahun 2012 - 2016 bernilai negatif sebesar -0.0213. hal ini berarti CAR berpengaruh negatif terhadap ROA. Nilai koefisien CAR sebesar $-0.0213 \%$ menunjukan bahwa jika CAR meningkat satu persen, maka ROA akan mengalami penurunan sebesar $-0.0213 \%$ dengan asumsi variabel lain dalam persamaan regresi bersifat konstan.

Pengaruh NPL terhadap profitabilitas (ROA) perbankan selama 5 tahun periode pengamatan bernilai negatif dengan koefisien regresinya sebesar 0.0221. kondisi ini menunjukan bahwa terdapatnya pengaruh negarif NPL terhadap ROA. Jika NPL meningkat satu persen, maka ROA mengalami penurunan sebesar $-0.0221 \%$ selama tahun 2012 - 2016 dengan asumsi variabel lain dalam persamaan regresi bersifat konstan.

Untuk pengaruh NIM terhadap profitabilitas (ROA) perbankan selama 5 tahun periode pengamatan tahun 2012 - 2016 bernilai positif dengan koefisien regresinya sebesar 0.2354 . kondisi ini menunjukan bahwa terdapatnya pengaruh positif NIM terhadap ROA. Jika NIM mengalami peningkatan satu persen, maka ROA mengalami peningkatan sebesar $0.2354 \%$ dengan asumsi variabel lain dalam persamaan regresi bersifat konstan.

Pengaruh BOPO terhadap profitabilitas (ROA) perbankan selama 5 tahun periode pengamatan bernilai negatif dengan koefisien regresinya sebesar 0.0832. kondisi ini menunjukan bahwa terdapatnya pengaruh negarif BOPO terhadap ROA. Jika BOPO meningkat satu persen, maka ROA mengalami penurunan sebesar $-0.0832 \%$ selama tahun $2012-2016$ dengan asumsi variabel lain dalam persamaan regresi bersifat konstan. 
Selanjutnya untuk pengaruh LDR terhadap profitabilitas (ROA) perbankan selama 5 tahun periode pengamatan tahun 2012 - 2016 bernilai negatif dengan koefisien regresinya sebesar -0.0051 . kondisi ini menunjukan bahwa terdapatnya pengaruh negatif LDR terhadap ROA. Jika NIM mengalami peningkatan satu persen, maka ROA mengalami penurunan sebesar $-0.0051 \%$ dengan asumsi variabel lain dalam persamaan regresi bersifat konstan.

\section{Uji Statistik F}

Uji statistik $\mathrm{F}$ dilakukan untuk menguji bagaimana pengaruh variabel bebas terhadap variabel terikat secara simultan atau keseluruhan. Hasil uji statistik $\mathrm{F}$ dapat dilihat pada tabel hasil 4.4. hasil estimasi mengindikasikan bahwa nilai $\mathrm{F}_{\text {hitung }}=197,4177$ dengan $\mathrm{F}_{\text {tabel }}$ yaitu $\alpha=5 \% ; \mathrm{F}_{\text {tabel }}=\mathrm{f} \alpha \mathrm{df}(\mathrm{k}-1) ;(\mathrm{n}-(\mathrm{K}-1))$. Jadi, $F_{\text {tabel }}=(0,05 ; 5 ; 95)=2,31$ sehingga $F_{\text {hitung }}>F_{\text {tabel }}(197,4177>2,31)$.hal ini dapat disimpulkan bahwa adanya hubungan secara simultan atau bersama - sama antara variabel bebas dengan variabel terikat.

\section{Uji Statistik T}

Adanya pengaruh CAR, NPL,NIM,BOPO dan LDR terhadap ROA selama tahun pengamatan yaitu 2012 - 2016 dapat dibuktikan dan dilihat pada tabel 4.4. pengujian nilai $t$ dilakukan dengan menggunakan $t$ hitung dan melihat probabilitas pada level signifikan $(\alpha=0,05)$. Pengujian t dilakukan untuk melihat berapa besarnya pengaruh setiap variabel bebas terhadap variabel terikat. Uji ini dilakukan dengan membandingkan nilai probabilitas yang didapat dengan nilai signifikan 5\%, jika nilai probabilitas yang didapat kecil dari 0,05 maka variabel tersebut dapat dikatakan berpengaruh dan jika mendapat besar dari 0,05 maka dapat dikatakan tidak berpengaruh.

Hipotesis pertama dalam penelitian ini adalah Capital Adequacy Ratio (CAR) berpengaruh positif terhadap profitabilitas (ROA) perbankan yang terdaftar di BEI yang menjadi sampel penelitian. Berdasarkan tabel 4.4 CAR mendapatkan nilai probabilitas sebesar $0,0008<0,05$ sehingga dapat disimpulkan bahwa Capital Adequacy Ratio (CAR) berpengaruh positif terhadap Profitabilitas (ROA). Oleh karena itu hipotesis pertama diterima.

Hipotesis kedua dalam penelitian ini adalah Non Performing Loan (NPL) berpengaruh positif terhadap profitabilitas (ROA) perbankan yang terdaftar di BEI yang menjadi sampel penelitian. Berdasarkan tabel 4.4 CAR mendapatkan nilai probabilitas sebesar 0,55088>0,05 sehingga dapat disimpulkan bahwa Non Performing Loan (NPL) tidak berpengaruh terhadap Profitabilitas (ROA). Oleh karena itu hipotesis kedua $\left(\mathrm{H}_{2}\right)$ ditolak.

Hipotesis ketiga dalam penelitian ini adalah Net Interest Margin (NIM) berpengaruh positif terhadap profitabilitas (ROA) perbankan yang terdaftar di BEI yang menjadi sampel penelitian. Berdasarkan tabel 4.4 CAR mendapatkan nilai probabilitas sebesar $0,0000<0,05$ sehingga dapat disimpulkan bahwa Net Interest Margin (NIM) berpengaruh positif terhadap Profitabilitas (ROA). Oleh karena itu hipotesis ketiga $\left(\mathrm{H}_{3}\right)$ diterima.

Hipotesis keempat dalam penelitian ini adalah Biaya Operasional Pendapatan Operasional (BOPO) berpengaruh positif terhadap profitabilitas (ROA) perbankan yang terdaftar di BEI yang menjadi sampel penelitian. Berdasarkan tabel 4.4 CAR mendapatkan nilai probabilitas sebesar 0,0000 $<0,05$ 
sehingga dapat disimpulkan bahwa Biaya Operasional Pendapatan Operasional (BOPO) berpengaruh positif terhadap Profitabilitas (ROA). Oleh karena itu hipotesis empat $\left(\mathrm{H}_{4}\right)$ diterima.

Hipotesis kelima dalam penelitian ini adalah Likuiditas (LDR) berpengaruh positif terhadap profitabilitas (ROA) perbankan yang terdaftar di BEI yang menjadi sampel penelitian. Berdasarkan tabel 4.4 CAR mendapatkan nilai probabilitas sebesar 0,0785 > 0,05 sehingga dapat disimpulkan bahwa Likuiditas (LDR) tidak berpengaruh terhadap Profitabilitas (ROA). Oleh karena itu hipotesis lima $\left(\mathrm{H}_{5}\right)$ ditolak.

\section{Koefisien Determinasi $\left(\mathbf{R}^{2}\right)$}

Koefisien determinasi atau disebut juga dengan Good of Fit digunakan untuk menunjukan proporsi variasi variabel terikat yang dapat dijelaskan oleh variabel bebas. Nilai $\mathrm{R}^{2}$ selalu terletak antara 0 dan 1 karena nilai Sum Square Explained (SSE) dan nilai Sum Square Residual (SSR) tidak mungkin melebihi nilai sum square total (SST). Dimana nilai $\mathrm{R}^{2}$ merupakan suatu ukuran kesesuaian model (model fit). Apabila nilai $\mathrm{R}^{2}$ kecil atau mendekati angka 0 berarti kemampuan variabel bebas dalam menjelaskan variabel terikat amat terbatas. Dan sebaliknya nilai $\mathrm{R}^{2}$ mendekati angka 1 berarti variabel bebas mampu menjelaskan hampir semua informasi yang dibutuhkan untuk memprediksi variabel terikat sehingga model tersebut dapat dikatan sangat baik.

Hasil koefisien determinasi $\mathrm{R}^{2}$ dapat dilihat pada tabel 4.4, nilai yang diperoleh sebesar 0,9130 atau 91,30\%. Dalam penelitian ini kemampuan variabel bebas yaitu Capital Adequacy Ratio (CAR), Non Performing Loan (NPL), Net Interest Margin (NIM), Biaya Operasional Pendapatan Operasional (BOPO) dan Likuiditas (LDR) mampu menjelaskan variabel terikat yaitu profitabilitas (ROA) perbankan selama tahun 2012 - 2016 sebesar 91,30\%. Dengan demikian dapat disimpulkan bahwa variabel bebas dapat menjelaskan variabel terikat sebesar $91,30 \%$ dalam penelitian ini dan sisanya sebesar $8,70 \%$ dijelaskan oleh variabel lain yang tidak dimasukan dalam penelitian ini.

\section{KESIMPULAN}

Berdasarkan pembahasan yang telah dilakukan pada Bab sebelumnya, maka dapat disimpulkan Capital Adequacy Ratio (CAR) berpengaruh negatif dan signifikan terhadap profitabilitas yang diukur dengan Return On Assets (ROA) perbankan yang terdaftar di BEI. Kualitas Aset Produktif (NPL) berpengaruh negatif dan tidak signifikan terhadap profitabilitas yang diukur dengan Return On Assets (ROA) perbankan yang terdaftar di BEI. Kualitas Manajemen (NIM) berpengaruh positif dan signifikan terhadap profitabilitas yang diukur dengan Return On Assets (ROA) perbankan yang terdaftar di BEI. Biaya Operasional Pendapatan Operasional (BOPO) berpengaruh negatif dan signifikan terhadap profitabilitas yang diukur dengan Return On Assets (ROA) perbankan yang terdaftar di BEI. Likuiditas (LDR) berpengaruh negatif dan tidak signifikan terhadap profitabilitas yang diukur dengan Return On Assets (ROA) perbankan yang 


\section{UCAPAN TERIMA KASIH}

Dalam penulisan skripsi dan dibuatnya artikel penelitian ini penulis tidak terlepas dari hambatan dan rintangan. Namun demikian, atas bimbingan, bantuan, arahan serta dukungan dari berbagai pihak, maka penulis dapat menyelesaikan skrpisi ini. Oleh karena itu penulis mengucapkan terima kasih kepada :

1. Bapak Febryandhie Ananda, SE, M.Si selaku ketua STIE 'KBP’ Padang.

2. Ibuk Lidya Martha, SE, MM selaku wakil ketua STIE 'KBP’ Padang.

3. Ibuk Aminar Sutra Dewi, SE, M,Si selaku Ketud Prodi Manajemen

4. Ibuk Desfriana Sari, SE, MM dosen pembimbing dalam penyusunan proposal

5. Keluarga besar yang telah mendoakan dan memberikan semangat serta bantuan moril dan materil kepada peneliti.

6. Teman-teman satu angkatan dan rekan-rekan mahasiwa-mahasiswi.

7. Semua pihak yang tidak dapat disebutkan satu persatu dan telah memberikan petunjuk dan inspirasi dalam penyusunan proposal ini.

\section{DAFTAR PUSTAKA}

Aini, N. (2013). Pengaruh CAR, NIM, LDR, NPL, BOPO, KAP Terhadap PerubahanLaba., 2(1), 14-25.

Afriyeni, A., \& Marlius, D. (2017). Analisis Pengaruh Harga Saham Perdana Terhadap Abnormal Return Yang Diterima Investor Studi Pada Bursa Efek Indonesia. https://doi.org/10.31219/osf.io/8z7hx

Afriyeni, A., \& Marlius, D. (2018). Analisis Pengaruh Informasi Prospektus Perusahaan Terhadap Initial Return Saham Pada Pasar Perdana Di Bursa Efek Indonesia. https://doi.org/10.31219/osf.io/kt6c4

Afriyeni, A., \& Marlius, D. (2019). Analisis Faktor-Faktor Yang Berpengaruh Terhadap Ketepatan Waktu Penyampaian Laporan Keuangan Pada Perusahaan Yang Listing Di Bursa Efek Indonesia. https://doi.org/10.31219/osf.io/rv4qf

Afriyeni, A., \& Marlius, D. (2019). Analisis Tingkat Pengembalian Dan Risiko Investasi (Studi Pada Industri Manufaktur Yang Terdaftar Di Bursa Efek Indonesia). https://doi.org/10.31219/osf.io/cfb92

Arifin, I. Z., \& Marlius, D. (2017). Analisis Kinerja Keuangan PT. Pegadaian Cabang Ulak Karang. https://doi.org/10.31227/osf.io/n2peu

Alhaq, M., Taufik, T., \& Desmiyawati. (2011). Pengaruh CAR, KAP, NPL dan LDR Terhadap Profitabilitas Perusahaan Perbankan Yang Terdaftar di Bursa EFek Indonesia Periode 2008 - 2010. 
Alifah, Y. B. (2014). Pengaruh CAR, NPL, BOPO dan LDR terhadap Profitabilitas Bank (ROA) Pada Perusahaan Perbankan Yang Terdaftar Di Bursa Efek Indonesia Periode 2009 - 2012.

Arinta, M. F. (2015). Pengaruh Capital Adequacy Ratio ( CAR ) Dan Loan To Deposit Ratio ( LDR ) Terhadap Profitabilitas Perusahaan Perbankan Yang Terdaftar Di Bursa Efek Indonesia Tahun 2011-2013.

Bilian, F., \& Purwanto. (2014). Analisis Pengaruh CAR, NIM, BOPO, dan LDR Terhadap Profitabilitas Bank Persero $12,155-168$.

Darmawi, H. (2012). Manajemen Perbankan. Jakarta: Bumi Aksara.

Fernos, J, Dona, E (2018). Analisis Loan To Deposit Ratio, Capital Adequacy Ratio Dan Return On Assets PT. Bank Pembangunan Daerah Sumatera Barat. Jurnal Pundi 2 (2)

Ghozali, I. (2013). Aplikasi Analisis Multivariate dengan Program SPSS Edisi Ketujuh. Semarang: Badan Penerbit Universitas Diponegoro.

Gujarati, D. N., \& Porter, D. C. (2012). Basic Econometris. Jakarta: Salemba Empat.

Hanafiah, I. (2015). Analisis Tingkat Kesehatan Bank (Studi Kasus Pada PT. Bank Nagari Sumatera Barat Periode 2010 - 2014).

Harmono. (2011). Manajemen Keuangan Berbasis Balanced Scorecard Pendekatan Teori, Kasus dan Riset Bisnis. Jakarta: Bumi Aksara.

Harun, U. (2016). Pengaruh Ratio-Ratio Keuangan CAR, LDR, NIM, BOPO, NPL Terhadap ROA, 67-82.

Handayani, M., \& Marlius, D. (2017). Analisis Tingkat Kesehatan PT. BPR Batang Kapas. https://doi.org/10.31227/osf.io/bq48z

Hutagalung, E. N., Djumahir, \& Ratnawati, K. (2011). Analisis Rasio Keuangan Terhadap KInerja Bank Umum di Indonesia.

Ichwan, F. Y., \& Widyawati, D. (2015). Pengaruh Ukuran Perusahaan, Struktur Aktiva dan Profitabilitas Terhadap Struktur Modal, 4(6), 1-19.

Infobanknews. (2013). Pendekatan Terbaru Rantin 120 Bank. Retrieved from http://www.infobanknews.com/2013/09/pendekatan-terbaru-ranting-120bank/

Ismail. (2011). Manajemen Perbankan dari Teori Menuju Aplikasi. Jakarta: Kencana.

Iswi, H. (2010). Restrurisasi dan Penghapusan Kredit Macet Kenapa Perbankan Memanjakan Debitur Besar Sedangkan Usaha/Debitur Kecil Dipaksa. Jakarta: PT. Elex Media Komputindo.

Kasmir. (2012). Dasar - Dasar Perbankan. Jakarta: PT. Raja Graindo Persada. Kasmir. (2013). Analisis Laporan Keuangan. Jakarta: PT. Raja Graindo Persada. 
Prasanjaya, A. A. Y., \& Ramantha, I. W. (2013). Analisis pengaruh rasio car, bopo, ldr dan ukuran perusahaan terhadap profitabilitas bank yang terdaftar di bei, 1, 230-245.

Pratiwi, L. P. S. W., \& Wiagustini, N. L. P. (2015). Pengaruh CAR , BOPO, NPL DAN LDR Terhadap Profitabilitas, 5(4), 2137-2166.

Rahmadhani, T. (2016). Pengaruh CAR, NIM, LDR, NPL DAN BOPO Terhadap Perubahan Laba Perusahaan Perbankan Yang Terdaftar Di Bursa Efek Indonesia Tahun 2013-2016, (6).

Rahmayeli, D. S., \& Marlius, D. (2017). Analisis Kinerja Keuangan Pada PT. Bank Perkreditan Rakyat (BPR) Batang Kapas Pesisir Selatan. https://doi.org/10.31227/osf.io/sz5db

Rodiyah, \& Wibowo, H. (2016). Pengaruh Rasio Indikator Tingkat Kesehatan Bank Terhadap Pertumbuhan Laba Pada Perusahaan Perbankan Yang Terdaftar Di BEI Periode Tahun 2009-2013, XIV(1), 39-57.

Sansoethan, D. K., \& Suryono, B. (2016). Faktor-Faktor yang Mempengaruhi Struktur Modal pada Perusahaan Makanan dan Minuman, 5, 1-20.

Sari, E. K. (2010). Analisis Pengaruh CAR, NPL, BOPO, NIM, LDR Dan Pemenuhan PPAP Terhadap Kinerja Perbankan.

Septiadi, B. (2014). Pengaruh CAR, Kualitas Aset Produktif, Kualitas Manajemen dan Likuiditas Terhadap Profitabilitas Perbankan Yang Terdaftar di Bursa Efek Indonesia.

Shanjaya, A. R., \& Marlius, D. (2017). Peranan Laporan Keuangan Dalam Kebijaksanaan Pemberian Kredit Kepada Calon Nasabah Pada PT. BPR Batang Kapas. https://doi.org/10.31227/osf.io/uxmg6

Sindonews. (2013). Mengggas Indikator Efisinesi. Retrieved from http://m.sindonews.com/read/2013/02/20/18/719656/menggagas-indikatorefisiensi/big.

Supraba, D. N. (2011). Analisis Pengaruh Efisiensi Operasi , Kualitas Aktiva , Permodalan, Dan Likuiditas Terhadap Profitabilitas Bank Umum Di Indonesia.

Wibisono, K. (2013). Analisis Pengaruh CAR, NPL, NIM dan LDR Terhadap ROA pada Bank UMum Swasta Nasional di Indonesia, 1. 